\title{
ANNUAL REPORT \\ OF THE BOARD OF REGENTS OF \\ THE SMITHSONIAN INSTITUTION
}

SHOWING THE OPERATIONS, EXPENDITURES

AND CONDITION OF THE INSTITUTION

FOR THE YEAR ENDING JUNE 30

\section{0}

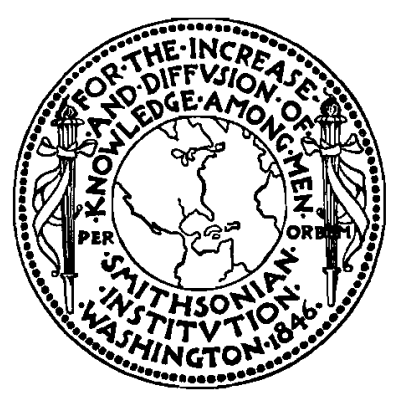

WASHINGTON

GOVERNMENT PRINTING OFFICE

1911 
$\$ 12,000$ a year, which is placed under the direction of the Smithsonian Institution for the specific purpose of carrying on scientific studies, particularly of American mammals and other animals, the donor specifying Dr. C. Hart Merriam as the investigator to carry on the work during his lifetime.

\section{BIOLOGICAL SURVEY OF THE PANAMA CANAL ZONE.}

The Institution has had in contemplation for some time several important scientific explorations, and it is gratifying to state that it now seems possible that one of them-an exhaustive biological survey of the Panama Canal Zone-will be undertaken in the winter of 1910-11. Definite plans for this survey have not been decided upon at present, but these are now under consideration and it is hoped that all the arrangements may be completed and the work put in hand in a few months.

It is particularly important to science that a biological survey of the Canal Zone be made at this time, as it appears without question that it would yield important scientific results, both as regards additions to knowledge and to the collections of the United States National Museum and other museums. While the Isthmus is not . so well endowed with large forms as the great continental areas, such as Africa, southern Asia, and some other regions, yet its fauna and flora are rich and diversified. The collecting which has been carried on there has been on such a rather limited scale, and chiefly along trade routes, that an extensive and thorough survey would surely produce new scientific information of great value.

A part of the fresh-water streams of the Isthmus of Panama empty into the Atlantic Ocean and others into the Pacific Ocean. It is known that a certain number of animals and plants in the streams on the Atlantic side are different from those of the Pacific side, but as no exact biological survey has ever been undertaken the extent and magnitude of these differences have yet to be learned. It is also of the utmost scientific importance to determine exactly the geographical distribution of the various organisms inhabiting those waters, as the Isthmus is one of the routes by which the animals and plants of South America have entered North America and vice versa. When the canal is completed the organisms of the various watersheds will be offered a ready means of mingling together, the natural distinctions now existing will be obliterated, and the data for a true understanding of the fauna and flora placed forever out of reach.

By the construction of the Gatun dam a vast fresh-water lake will be created, which will drive away or drown the majority of the animals and plants now inhabiting the locality, and quite possibly exterminate some species before they become known to science. 
The National Museum at present has practically no Panama mammals. The birds now in the collection are chiefly from along the line of the railroad and from Chiriqui. It has comparatively few reptiles. The fresh-water fishes are poorly represented in the collections and are of special importance for comparison with South American forms. Land and fresh-water mollusks are much needed. The National Herbarium is poorly supplied with Panama plants; in fact, they are at present practically "a negligible quantity," and the American herbariums taken together do not contain a sufficient amount of material to form the basis of a general flora of Panama, which is a work much needed.

ANTIQUITY OF MAN IN SOUTH AMERICA.

In March, 1910, the Institution directed Dr. Aleš Hrdlička, Curator of the Division of Physical Anthropology, United States National Museum, to proceed to South America and Panama Canal Zone for the purpose of making anthropological researches, and particularly to undertake investigation into the question of man's antiquity in Argentina. A grant was also made to enable Mr. Bailey Willis, of the United States Geological Survey, proceading on his way to South America in the interest of the world's topographical map, to cooperate with Doctor Hrdlička in his researches in Argentina, for it was appreciated that the problems to be met with were to an important degree of a geological nature.

The undertaking of the investigation was especially due to Mr. W. H. Holmes, Chief of the Bureau of American Ethnology, whose observations during a visit to Argentina in 1908 made apparent the far-reaching importance of the data being collected bearing on human antiquity in South America.

The subject of man's antiquity in South America dates from the meager reports concerning the scattered remains in the Lagoa Santa caves in Brazil, the casual Seguin finds in the province of Santa Fe, Argentina, and the Moreno collection of old Patagonian material in the valley of Rio Negro, and it has assumed a special importance during the last decade through a relatively large number of reports by Argentinian scientists, but particularly by Prof. F. Ameghino, of new finds of the remains of ancient man and of traces of his activities. Some of these more recent finds were so interpreted that, if corroborated, they would have a most important bearing not merely on man's early presence in the South American Continent, but on the evolution and the spread of mankind in general.

Under these conditions, and in view of the fact that some of the reports were not fully satisfactory as to their anatomical or geological details, it was deemed necssary to send down competent men who might subject the whole matter to critical revision. 
It is gratifying to state that on arriving at Argentina and explaining their mission the Smithsonian representatives were afforded by the Argentinian Government, as well as by the Argentinian men of science, all facilities needed for the examination of the specimens preserved in various institutions, as well as for the prosecution of their field work. Professor Ameghino and his brother, Carlos, gave particular aid, accompanying Doctor Hrdlička and Mr. Willis personally for over three weeks along the coast from place to place where the supposedly ancient remains were discovered.

The researches occupied nearly two months. Every specimen relating to ancient man that could still be found was examined, and every locality of importance where the finds were made was visited and investigated. 'The evidence gathered, unfortunately, does not sustain a large part of the claims that have been made. The human bones and the archeological specimens which should represent geologically ancient man agree in all important characteristics with the bones and work of the American Indian; and the finds, while often in close rclation with early Quaternary or Tertiary deposits, bear, so far as observed, only intrusive relations to these deposits. Furthermore, there are specimens the original sources of which are not so well established that scientific deductions of great consequence can be safely drawn therefrom, even though they present some morphological peculiarities.

The expedition secured numerous geological, paleontological, and anthropological specimens, some of which throw much light on the question of the antiquity of the finds to which they relate. These specimens are being identified and described in the National $\mathbf{M u -}$ seum. Doctor Hrdlička and Mr. Willis will present in due time a detailed report on their investigations.

Following the researches in Argentina, Doctor Hrdlička visited several of the anthropologically important localities on the coast of Peru and made large collections of skeletal material, which will help to settle definitely the racial problems of these regions, and will have an important bearing on the anthropology of the western part of South America.

Further explorations and collections, necessarily limited, were made by Doctor Hrdlička in Panama and Mexico. In the latter country the principal results of the visit were the opening, at the invitation of the Mexican authorities, of a highly interesting sepulcher in the ancient ruins of San Juan Teotihuacan, and the making of a series of casts from the remaining pure bloods among the Aztec descendants in Xochimilco.

The Argentina, as well as the Peruvian and Mexican, collections have been transferred to the U. S. National Museum. 